\title{
FACE VALIDATION OF AN EDUCATIVE MANUAL FOR HEAD AND NECK CANCER PATIENTS SUBMITTED TO RADIOTHERAPY
}

\author{
VALIDACÃO DE APARENNCIA DE MANUAL EDUCATIVO PARA PACIENTES COM \\ CÂNCER DE CABEÇA E PESCOÇO SUBMETIDOS À RADIOTERAPIA
}

\section{Flávia Oliveira de Almeida Marques da CRUZ ${ }^{1}$; Elaine Barros FERREIRA ${ }^{2}$; Priscila Souza Maggi BONTEMPO ${ }^{3}$; Christiane Inocêncio VASQUES ${ }^{4}$; Paula Elaine Diniz dos REIS}

1. Enfermeira, Doutoranda em Ciências da Saúde, Programa de Ciências da Saúde - PPGCS, Universidade de Brasília - UnB, Brasília, DF, Brasil. flaviaoamcruz@gmail.com; 2. Enfermeira, Doutora em Enfermagem, Universidade de Brasília - UnB, Brasília, DF, Brasil; 3. Enfermeira, Mestre em Enfermagem, Universidade de Brasília - UnB, Brasília, DF, Brasil; 4. Enfermeira, Doutora em Enfermagem, Professora do Programa de Pós-graduação em Enfermagem - PPGENF, Universidade de Brasília - UnB, Brasília, DF, Brasil; 5.

Enfermeira, Doutora em Enfermagem, Professora do Programa de Pós-graduação em Ciências da Saúde - PPGCS, Universidade de Brasília - UnB, Brasília, DF, Brasil.

\begin{abstract}
: execute the face validation of the educative manual for head and neck cancer patients submitted to radiotherapy. Methodological and descriptive research. The sample consisted of 11 patients, divided in four groups according to the instruction level. An Agreement Rate of at least $80 \%$ was considered to guarantee the validation of the material with regard to its semantic analysis. The items addressed in the evaluation tool of the educative manual were divided in five blocks: objectives, organization, writing style, appearance and motivation. Only one item, related to the cover of the material, obtained an Agreement Rate $<80 \%$ and was reformulated based on the participants' suggestions. All other items were considered appropriate and/or totally appropriate in the five blocks proposed: objectives - $100 \%$, structure and presentation $-93.93 \%$, writing style $-95.45 \%$, appearance $-97.72 \%$, and motivation $-93.50 \%$. The analysis of the face validation of the educative manual proposed demonstrated that it is apt for use as a guide during the nursing consultation, in order to support nursing care for head and neck cancer patients submitted to radiotherapy.
\end{abstract}

KEYWORDS: Oncology Nursing. Health Education. Nursing Care. Validation Studies. Educational Technology.

\section{INTRODUCTION}

The term head and neck cancer characterizes the malign tumors of the upper aerodigestive tract, including the oral cavity, pharynx and larynx (MELO FILHO et al, 2013). Cancer in this region entails a huge impact in the patients' daily life, besides imposing intense physical, social and psychological suffering, as it affects the most visible area of the body and fundamental activities of daily living, such as speech, breathing and nutrition (EGESTAD, 2013; PAULA et al, 2012; LICITRA, MESÍA, KEILHOLZ, 2016). In addition, the treatment of this disease is associated with adverse effects. The most common adverse effects associated with radiotherapy in the head and neck region are mucositis, xerostomia, taste alteration, dental caries and radiodermatitis (MELO FILHO et al, 2013).

Nurses do not only maintain their role related to the maintenance of the treatment and its adverse effects, but should also transmit information on the disease and the treatment, offer relief measures and help patients and relatives to cope with the disease (SALLES, CASTRO, 2010). Therefore, nursing care delivered to this population faces challenges related to the different physical and psychosocial demands involved, which need to be attended to through specialized theoretical and practical knowledge, besides different forms of communication involving care (GILL, DUFFY, 2010).

Educative manuals play an important role as a support strategy for health education activities, as they help individuals to understand the information transmitted and serve as readily available material for the patients and their families to use at home (FREITAS, CABRAL, 2008). In that context, different studies are found in the literature for the elaboration of educative tools that can support and systemize nursing work. In one study, an educative manual was validated for the promotion of self-care in mastectomized women (OLIVEIRA, FERNANDES, SAWADA, 2008), another analyzed the communication resources of an educative booklet for care delivery to tracheostomized people (FREITAS, CABRAL, 2008), and yet another validated an educative game for dietary orientations to diabetes mellitus patients (MOURA et al, 2008). A study was also undertaken to elaborate and validate a flip chart to promote maternal selfefficacy in breastfeeding (DODT, XIMENES, 
ORIA, 2012) and another was focused on validating an educative guidebook for healthy eating during pregnancy (OLIVEIRA, LOPES, FERNANDES, 2014).

Therefore, it is pertinent and relevant to use material that contains information about head and neck cancer, the possible adverse effects related to the treatment, as well as about prevention and/or the administration of these effects, with a view to promoting health education and favoring self-care at home for this population. Thus, the objective in this study was to describe the face validation executed by the target population of an educative manual to orient head and neck cancer patients submitted to radiotherapy.

\section{MATERIAL AND METHODS}

A methodological and descriptive research was undertaken, focused on the development, assessment and improvement of a methodological strategy (POLIT, BECK, 2011). The construction and validation of the educative manual, executed by experts in the theme area of the tool, were developed in an earlier study, which was limited by the lack of face validation by the target population (CRUZ et al, 2016). Therefore, to proceed with the validation process of the educative manual, in this study, the face validation of the material is presented, executed by the head and neck cancer patients submitted to radiotherapy at the High Complexity Care Center in Oncology (CACON) at the University Hospital in Brasília (HUB), Federal District - DF.

The manual, called "Orientation manual: radiotherapy in head and neck", was focused on patients with head and neck cancer under treatment at the Radiotherapy Outpatient Clinic of the CACON/HUB. The size of the manual is $190 \times 280$ $\mathrm{mm}$, with 38 pages. It is organized in pre-textual (cover, back cover, cataloguing, summary and presentation), textual (chapters about cancer, radiotherapy, treatment phases, adverse effects of the radiotherapy and how to prevent them, tracheotomy and nasogastric tube) and post-textual elements (final information, bibliographic references and weekly diary).

The semantic analysis, an important aspect of the face validation, is intended to verify whether the manual is understandable to the members of the target population, mainly if it is clear, easy to read and understand (PASQUALI, 1997). To develop this analysis, the manual was applied to the patients attended at the CACON/HUB, diagnosed with malign head and neck tumors, submitted to radiotherapy, over 18 years of age, able to understand to content, availability to participate in the assessment process of the educative manual and who were at least in the second week of treatment, that is, as from the sixth radiotherapy session. The latter criterion was necessary to guarantee that the participant had sufficient knowledge and experience to assess the material, considering that, in that period, the patient had already experienced the treatment and had received different orientations about it, whether in group during the institutional welcoming or individually during the medical and nursing appointments.

The selected patients received instructions on the study proposal and, after accepting and signing the Informed Consent Form, they received the manual and the assessment tool. The evaluation process took place between June 2015 and January 2016, in the patient's treatment environment, to facilitate the patient's access to the material and guarantee the reliability of the process. Individually, each patient read the educative manual and completed the assessment tool, without the researcher's interference.

The sample consisted of 11 patients, who were divided in four groups, organized according to the participants' instruction level, considering that, in the semantic analysis, the accessibility of the tool for the population group with the lowest level of understanding should be verified. At the same time, the material should not seem awkward to the population group whose skills are more developed. This technique is called Brainstorming, in which small groups of up to four people assess the material, starting with the group with the lowest instruction level (PASQUALI, 1997). This technique had to be adapted, as the patients could not be grouped for a joint analysis of the material. Therefore, after returning the completed tool, the participants were organized in four groups according to their instruction level, and the individual answers were analyzed inside each group.

To collect the information, an assessment form was used, adapted from an existing questionnaire (OLIVEIRA, 2006), after receiving the author's authorization and making the changes needed in relation to theme discussed in the educative manual of this study. This tool permitted exploring aspects related to the understanding of the material and its appearance. It was constructed in the form of a Likert scale, with five alternative answers: inappropriate (I); partially appropriate (PA); I am not sure (N); appropriate (A); and totally appropriate (TA). The options A and TA were grouped to represent the appropriateness of the item, 
while the options $\mathrm{N}$ and PA represent indecision and option I represent an invalid item.

To determine the relevance of each item addressed in the assessment tool, a minimum agreement rate of $80 \%$ was set among the participantsl (PASQUALI, 1997). The group comprising options A and TA should obtain at least $80 \%$ of the answers to guarantee its validity. The item that scored less than $80 \%$ of agreement was reformulated based on the participants' suggestions. The data were typed, processed and analyzed through descriptive statistics.

The research project was submitted to the Research Ethics Committee at the University of Brasília School of Health Sciences (CEP/FS-UnB), approved through opinion 493.456, CAAE: 24592213.1.0000.0030. The ethical aspects of the research were taken into account in accordance with National Health Council Resolution 466, from $12 / 12 / 12$, which establishes regulatory ethical guidelines for research involving human beings (BRASIL, 2012)

\section{RESULTS}

The sample consisted of 11 patients, including seven men and four women. According to the Brainstorming technique, the participants were divided in groups according to their education. Group 1 consisted of participants who studied until the $4^{\text {th }}$ grade $/ 5^{\text {th }}$ year (2 participants), group 2 until the $8^{\text {th }}$ grade $/ 9^{\text {th }}$ year (4 participants), group 3 until the $3^{\text {rd }}$ year of secondary education ( 3 participants), and group 4 consisted of patients who had taken higher education ( 2 participants). The participants' age ranged between 19 and 78 years $($ mean $(\bar{x})=$ 53.91 years \pm 19.76 ). As regards the skin color, seven participants self-declared mulatto and four self-declared white. About the marital status, five were single, three widowed and three married. Only one participant came from Goiás, while the remainder came from the Federal District. The location of the disease differed a lot, including the base of tongue, larynx, parotid, oropharynx, hypopharynx, amygdala and even the retromolar trigone.

Concerning the validation process of the educative manual, the participants' opinions were subject to quantitative analysis, through the answers given to the items in the assessment tool, which addressed five analysis blocks: objectives; structure and presentation; writing style; appearance; and motivation. At the end of each block, the participants could justify their answers and/or give suggestions related to the educative manual.

The participants' comments were as follows: "The manual was very well elaborated"; "If the patient and the family members follow the orientations that will certainly mitigate the suffering (...)"; "I would not change anything"; "As to the orientation manual, everything is very well clarified"; "The content addressed is very good".

Table 1 displays the participants' answers and the Agreement Rate (AR) of each item in the first assessment block, consisting of three items, which verified the patients' opinion on the objective and goal of the educative manual. All items reached a $100 \%$ AR, resulting in an average rate of $100 \%$ for the block.

Table 1. Patient assessment of objectives of educative manual. Brasília, DF, Brazil, 2016

\begin{tabular}{|c|c|c|c|c|c|c|}
\hline \multirow{2}{*}{ Assessment items } & \multicolumn{5}{|c|}{$\mathbf{n = 1 1}$} & \multirow{2}{*}{$\%^{\mathrm{q}}$} \\
\hline & $\mathbf{I}^{*}$ & $\mathbf{P A}^{\dagger}$ & $\mathbf{N}^{\ddagger}$ & $\mathbf{A}^{\S}$ & TA $^{\|}$ & \\
\hline $\begin{array}{l}\text { A - The manual informs on the needs of the patients in } \\
\text { radiotherapy }\end{array}$ & 0 & 0 & 0 & 3 & 8 & 100.00 \\
\hline B - Responds to these patients' objectives and doubts & 0 & 0 & 0 & 4 & 7 & 100.00 \\
\hline $\mathrm{C}-\mathrm{Can}$ help during the treatment & 0 & 0 & 0 & 5 & 6 & 100.00 \\
\hline Total & 0 & 0 & 0 & 12 & 21 & 100.00 \\
\hline
\end{tabular}

*Inappropriate; $\uparrow$ Partially appropriate; $\$$ I am not sure; $§$ Appropriate; ||Totally appropriate; $\uparrow$ Agreement rate calculated by adding up the number of appropriate and totally appropriate items according to the patients: TA+A x $100 /$ total answers.

Table 2 presents the patients' answers and the AR of each item in the second assessment block, which consisted of six items, aimed at checking the patients' opinion on the structure and presentation of the material. Item 2 did not reach the minimum
AR established, reaching $72.72 \%$. All other items in the block reached the $80 \%$ AR, ranging between 90.90 and $100 \%$. The mean AR of the block was $93.93 \%$. 
Table 2. Patient assessment of the structure and presentation of the educative manual. Brasília, DF, Brazil, 2016

\begin{tabular}{|c|c|c|c|c|c|c|}
\hline \multirow{2}{*}{ Assessment items } & \multicolumn{5}{|c|}{$\mathrm{n}=11$} & \multirow{2}{*}{$\%^{\text {II }}$} \\
\hline & $\mathbf{I}^{*}$ & $\mathbf{P A}^{\dagger}$ & $\mathbf{N}^{\ddagger}$ & $\mathbf{A}^{\S}$ & TA $^{\|}$ & \\
\hline $\begin{array}{l}\text { A - The cover is appealing and attracts the patient's } \\
\text { interest }\end{array}$ & 0 & 1 & 2 & 4 & 4 & 72.72 \\
\hline $\begin{array}{l}\text { B - The font size used in the titles and texts is } \\
\text { appropriate }\end{array}$ & 0 & 0 & 0 & 2 & 9 & 100.00 \\
\hline $\mathrm{C}$ - The content was addressed in a logical sequence & 0 & 0 & 0 & 3 & 8 & 100.00 \\
\hline $\begin{array}{l}\mathrm{D} \text { - The information is presented in a clear and objective } \\
\text { manner }\end{array}$ & 0 & 0 & 0 & 4 & 7 & 100.00 \\
\hline $\begin{array}{l}\text { E - The print material is appropriate (size of the manual, } \\
\text { type of paper and colors used) }\end{array}$ & 0 & 1 & 0 & 2 & 8 & 90.90 \\
\hline $\mathrm{F}-$ The number of pages is appropriate & 0 & 0 & 0 & 6 & 5 & 100.00 \\
\hline Total & 0 & 2 & 2 & 21 & 41 & 93.93 \\
\hline
\end{tabular}

*Inappropriate; $†$ Partially appropriate; $\$$ I am not sure; $\S$ Appropriate; $\|$ Totally appropriate; $\uparrow$ Agreement rate calculated by adding up the number of appropriate and totally appropriate items according to the patients: TA+A x $100 /$ total answers.

Table 3 presents the patients' answers and the AR of each item in the third assessment block, which consisted of four items, which assessed the characteristics of the writing used in the educative manual. All items reached $80 \%$ of AR, ranging from 81.81 to $100 \%$. The mean AR of the block was $95.45 \%$.

Table 4, in turns, presents the patients' answers and the AR of each item in the fourth assessment block, which consisted of four items, which assessed the visual characteristics of the educative material presented. All items reached an AR of $80 \%$, ranging from 90.90 to $100 \%$. The mean AR of the block was $97.72 \%$.

Finally, Table 5 presents the patients' answers and the RA of each item in the fifth assessment block, which consisted of seven items that assessed the ability of the educative manual to produce some impact, motivation or interest in the reader. All items reached $80 \%$ of AR, ranging from 81.81 to $100 \%$. The mean AR of the block was $93.50 \%$.

Table 3. Patient assessment of writing style of the educative manual. Brasília, DF, Brazil, 2016

\begin{tabular}{|c|c|c|c|c|c|c|}
\hline \multirow{2}{*}{ Assessment items } & \multicolumn{5}{|c|}{$\mathrm{n}=\mathbf{1 1}$} & \multirow{2}{*}{$\%^{\mathrm{qI}}$} \\
\hline & $I^{*}$ & $\mathbf{P A}^{\dagger}$ & $\mathbf{N}^{\ddagger}$ & $\mathbf{A}^{\S}$ & $\mathbf{T A}^{\|}$ & \\
\hline A - The text is clear and objective & 0 & 0 & 0 & 5 & 6 & 100.00 \\
\hline B - The font style used is appropriate & 0 & 0 & 0 & 4 & 7 & 100.00 \\
\hline $\mathrm{C}$ - The text is simple and easy to read & 0 & 0 & 0 & 5 & 6 & 100.00 \\
\hline $\begin{array}{l}\mathrm{D} \text { - The writing of the manual can reach different } \\
\text { patients }\end{array}$ & 0 & 0 & 2 & 4 & 5 & 81.81 \\
\hline Total & 0 & 0 & 2 & 18 & 24 & 95.45 \\
\hline
\end{tabular}

*Inappropriate; †Partially appropriate; $\$$ I am not sure; §Appropriate; ||Totally appropriate; $\uparrow$ Agreement rate calculated by adding up the number of appropriate and totally appropriate items according to the patients: TA+A x 100 / total answers. 
Table 4. Patient assessment of general outlook of educative manual. Brasília, DF, Brazil, 2016

\begin{tabular}{|c|c|c|c|c|c|c|}
\hline \multirow{2}{*}{ Assessment items } & \multicolumn{5}{|c|}{$\mathrm{n}=\mathbf{1 1}$} & \multirow{2}{*}{$\%^{\mathrm{TI}}$} \\
\hline & $\mathbf{I}^{*}$ & $\mathbf{P A}^{\dagger}$ & $\mathbf{N}^{\ddagger}$ & $\mathbf{A}^{\S}$ & TA $^{\|}$ & \\
\hline A - The pages and chapters are organized & 0 & 0 & 0 & 2 & 9 & 100.00 \\
\hline B - The pictures represent the actual treatment scenario & 0 & 0 & 0 & 4 & 7 & 100.00 \\
\hline $\begin{array}{l}\mathrm{C}-\text { The illustrations are simple and able to complement } \\
\text { the texts }\end{array}$ & 0 & 0 & 0 & 4 & 7 & 100.00 \\
\hline D - The illustrations are sufficient and appropriate & 0 & 1 & 0 & 4 & 6 & 90.90 \\
\hline Total & 0 & 1 & 0 & 14 & 29 & 97.72 \\
\hline
\end{tabular}

*Inappropriate; $†$ Partially appropriate; $\$$ I am not sure; $\S$ Appropriate; $\|$ Totally appropriate; $\llbracket$ AAgreement rate calculated by adding up the number of appropriate and totally appropriate items according to the patients: TA+A x $100 /$ total answers.

Table 5. Patient assessment of motivation the educative manual awakens. Brasília, DF, Brazil, 2016

\begin{tabular}{|c|c|c|c|c|c|c|}
\hline \multirow{2}{*}{ Assessment items } & \multicolumn{5}{|c|}{$\mathrm{n}=\mathbf{1 1}$} & \multirow{2}{*}{$\%^{\mathrm{q}}$} \\
\hline & $\mathbf{I}^{*}$ & $\mathbf{P A}^{\dagger}$ & $\mathbf{N}^{*}$ & $\mathbf{A}^{\S}$ & TA $^{\| \prime}$ & \\
\hline $\begin{array}{l}\text { A - The manual is appropriate to the patients' education } \\
\text { level }\end{array}$ & 0 & 0 & 2 & 3 & 6 & 81.81 \\
\hline B - The manual can reach different levels of education & 0 & 0 & 1 & 4 & 6 & 90.90 \\
\hline $\mathrm{C}-$ The patient is able to interact with the material & 0 & 1 & 0 & 4 & 6 & 90.90 \\
\hline $\begin{array}{l}\text { D - The manual discusses the necessary themes for head } \\
\text { and neck cancer patients submitted to radiotherapy }\end{array}$ & 0 & 0 & 0 & 3 & 8 & 100.00 \\
\hline E - Can help to promote behavioral and attitude change & 0 & 0 & 0 & 5 & 6 & 100.00 \\
\hline $\begin{array}{l}\text { F - The manual helps the patient to accomplish self-care } \\
\text { at home }\end{array}$ & 0 & 0 & 0 & 3 & 8 & 100.00 \\
\hline $\begin{array}{l}\mathrm{G} \text { - Can be used at home to guide the caregivers and } \\
\text { family members }\end{array}$ & 0 & 1 & 0 & 1 & 9 & 90.90 \\
\hline Total & 0 & 2 & 3 & 23 & 49 & 93.50 \\
\hline
\end{tabular}

*Inappropriate; †Partially appropriate; $\ddagger \mathrm{I}$ am not sure; $§$ Appropriate; $\|$ Totally appropriate; $\uparrow$ Agreement rate calculated by adding up the number of appropriate and totally appropriate items according to the patients: TA+A x 100 / total answers.

\section{DISCUSSION}

In general, the patients' answers showed agreement, as can be observed in the tables. Thus, the educative manual was considered appropriate for use in this population. Nevertheless, the participants' education level favored a limited number of considerations, as observed in a study that validated a booklet for mastectomized women (OLIVEIRA, FERNANDES, SAWADA, 2008). The few suggestions came from patients in group 4 and, in addition, few comments were given, all of which demonstrated satisfaction with the material, as can be observed in the excerpts displayed in the results.

The items in the first block (Table 10 refer to the objectives and purposes of using the educative manual. After analyzing the data, it could be verified that the material was considered valid in terms of its capacity to transmit information needed for the patients undergoing radiotherapy in the head and neck region, serving as important support during the treatment. The use of written material can be an effective strategy as a health education measure during nursing care, as it underlines the nurse's verbal orientations and is readily available 
for use at home (OLIVEIRA, LUCENA, ECHER, 2014).

The second assessment block (Table 2) shows the patients' judgment of the strategy used to present information in the manual, including the organization and structure. Item A, related to the cover of the material, reached $72.72 \%$ of AR, below the target established. Therefore, the participants' considerations were accepted and the cover was modified to become more colored, informal and lively, attracting more attention and awakening the patients' interest in reading the material. Aspects related to the presentation strategy of the orientations in educational material are very important, as the message transmitted should be credible and trustworthy, and also appropriate to the context of the target public, using only information considered essential for a correct understanding of the text (MOREIRA, NÓBREGA, SILVA, 2003).

The third block (Table 3), related to the characteristics of the writing used in the educative manual, also reached the minimum agreement rate set. Therefore, the text used in the material was considered clear, objective and easy to read, confirming the ability of the manual to be used for health education purposes during the nursing consultation involving head and neck cancer patients submitted to radiotherapy. It is fundamental to use language that is accessible to different social groups, independently of the instruction level of the target population, considering that the material needs to be easy to understand (OLIVEIRA, LUCEA, ECHER, 2014). This fact is related to the use of the Brainstorming technique, in which it can be assessed and guaranteed that the material is accessible to patients with lower education levels, while appropriate to those patients with a higher instruction level, in accordance with a study that validated a booklet for mastectomized women (OLIVEIRA, FERNANDES, SAWADA, 2008).

The printed educative manual can be widely used to facilitate the teaching-learning process, despite some restrictions due to reading difficulties. The reader's degree of education is closely related to this aspect. In Brazil, low education levels and illiteracy are relevant problems. Nevertheless, patients without education can also benefit from the advantages of printed material, as it is illustrated and can serve as support for the caregivers and family members (MOREIRA, NÓBREGA, SILVA, 2003).

The use of illustrations throughout the educative manual helps to transform textual information into visual language, encouraging the interest in reading it and facilitating the understanding of the material (OLIVEIRA, LUCEA, ECHER, 2014; OLIVEIRA, LOPES, FERNANDES, 2014). The fourth block (Table 4) assessed the visual characteristics of the educative manual, that is, the illustrations and photographs used throughout the material, with good assessment scores. Colored and attractive illustrations were used, in the attempt to make the material less impacting and more informal. Images play an important role in communication. Thus, the pictures used were taken from the treatment environment of the patients submitted to radiotherapy at the CACON/HUB, representing this population's actual scenario, turning the material more familiar and in accordance with the reality the patients experience.

The fifth block (Table 5) shows the patients' analysis according to the ability of the educative manual to arouse the reader's interest and provoke motivation for its use. All participants assessed that the material can help to promote behavioral change and stimulate the accomplishment of self-care at home. Offering information and orientations to the patient and relatives through printed educative material can be an important strategy to enhance the treatment compliance, besides facilitating the patients' acquisition of coping and decision making skills (SOUSA, TURRINI, 2012). When the patients take material home with instructions transmitted during the nursing consultation, this information transmission can continue beyond the hospital environment, disseminating it at home among the caregivers and relatives interacting with the patient. In addition, the education can be permanent, as the patient can constantly consult the material in case of doubts or anxiety (CRUZ et al, 2016).

Explanations on possible adverse reactions of the treatment can enhance the patients' understanding and satisfaction, without inducing increased anxiety, in accordance with the results of a study that tested the patients' knowledge, satisfaction and anxiety after receiving a booklet with detailed information on the laparoscopy and its adverse effects (GARRUD, WOOD, STAINSBY, 2001). In that context, the nursing consultation is fundamental to provide orientations on the treatment and the selfcare measures needed to prevent or minimize these effects. The educative manuals are important tools to guide and systemize these actions (ANDRADE et al, 2014).

It is highlighted that, after the validation process of the orientation manual, it needs to be used in a clinical trial to assess its effectiveness to generate behavioral changes in terms of self-care adherence. 


\section{CONCLUSION}

The appearance of the educative manual was validated. Through the participating patients' suggestions, the material could be improved and its final version was prepared for use as an orientation guide for head and neck cancer patients submitted to radiotherapy during nursing consultations at the High-Complexity Care Center in Oncology $(\mathrm{CACON})$ of the University Hospital in Brasília (HUB).

RESUMO: validar a aparência de manual educativo direcionado aos pacientes com câncer de cabeça e pescoço submetidos à radioterapia. Pesquisa metodológica, de caráter descritivo. A amostra foi composta por 11 pacientes, divididos em quatro grupos de acordo com o nível de instrução de cada um deles. Foi considerado o Índice de Concordância de, no mínimo, $80 \%$ para se garantir a validação do material em relação a sua análise semântica. Os itens abordados no instrumento de avaliação do manual educativo foram divididos em cinco blocos: objetivos, organização, estilo da escrita, aparência e motivação. Apenas um item, relacionado à capa do material, obteve Índice de Concordância < $80 \%$, a qual foi reformulada com base nas sugestões dos participantes. Todos os outros itens foram considerados adequados e/ou totalmente adequados nos cinco blocos propostos: objetivos - 100\%, estrutura e apresentação - 93,93\%, estilo da escrita - 95,45\%, aparência - 97,72\%, e motivação - 93,50\%. O manual educativo proposto foi considerado válido quanto à aparência, estando apto a ser utilizado enquanto guia de orientações para subsidiar a assistência de enfermagem prestada ao paciente com câncer de cabeça e pescoço submetido à radioterapia durante a consulta de enfermagem.

PALAVRAS-CHAVE: Enfermagem Oncológica. Educação em Saúde. Cuidados de Enfermagem. Estudos de Validação. Tecnologia Educacional.

\section{REFERENCES}

ANDRADE, K. B. S.; FRANCZ, A. C. L.; GRELLMANN, M. S.; BELCHIOR, P. C.; OLIVEIRA, J. A.; WASSITA, D. N. Consulta de enfermagem: avaliação da adesão ao autocuidado dos pacientes submetidos à radioterapia. Rev enferm UERJ, Rio de Janeiro, v. 22, n. 5, p. 622-8, 2014.

CRUZ, F. O. A. M.; FERREIRA, E. B.; VASQUES, C. I.; MATA, L. R. F.; REIS, P. E. D. Validação de manual educativo para pacientes com câncer de cabeça e pescoço submetidos à radioterapia. Rev Latino-Am Enferm. 2016. No prelo.

DODT, R. C. M.; XIMENES, L. B.; ORIA, M. O. B. Validation of a flip chart for promoting breastfeeding. Acta paul. enferm., v. 25, n. 2, p. 225-30, 2012. https://doi.org/10.1590/S0103-21002012000200011

EGESTAD, H. The significance of fellow patients for head and neck cancer patients in the radiation treatment period. Eur J Oncol Nurs., v. 17, n. 5, p. 618-24, oct. 2013. https://doi.org/10.1016/j.ejon.2013.01.001

FREITAS, A. A. S.; CABRAL, I. E. O cuidado à pessoa traqueostomizada: análise de um folheto educativo. Esc. Anna Nery Rev. Enferm., v. 12, n. 1, p. 84-9, mar. 2008. https://doi.org/10.1590/S141481452008000100013

GARRUD, P.; WOOD, M.; STAINSBY, L. Impact of risk information in a patient education leaflet. Patient educ. couns., v. 43, n. 3, p. 303-6, 2001. https://doi.org/10.1016/S0738-3991(00)00168-3

GILL, F.; DUFFY, A. Caring for cancer patients on non-specialist wards. Br J Nurs., v. 19, n. 12, p. 761-7, jun-jul. 2010. https://doi.org/10.12968/bjon.2010.19.12.48654

LICITRA, L.; MESÍA, R.; KEILHOLZ, U. Individualised quality of life as a measure to guide treatment choices in squamous cell carcinoma of the head and neck. Oral oncol., v. 2, n. 52, p. 18-23, 2016. https://doi.org/10.1016/j.oraloncology.2015.10.020 
MELO FILHO, M. R.; ROCHA, B. A.; PIRES, M. B. O.; FONSECA, E. S.; FREITAS, E. M.; MARTELLI JUNIOR, H.; SANTOS, F. B. G. Quality of life of patients with head and neck cancer. Braz J Otorhinolaryngol., v. 79, n. 1, p. 82-8, jan-feb. 2013. https://doi.org/10.5935/1808-8694.20130014

BRASIL. Ministério da Saúde. Conselho Nacional de Saúde. Comissão Nacional de Ética em Pesquisa. Resolução $n^{\circ} 466$ de 12 de dezembro de 2012. Diretrizes e normas regulamentadoras de pesquisa envolvendo seres humanos. Brasília, 2012.

MOREIRA, M. F.; NÓBREGA, M. M. L.; SILVA, M. I. T. Comunicação escrita: contribuição para a elaboração de material educativo em saúde. Rev. bras. enferm., v. 56, n. 2, p. 184-8, mar-abr. 2003. https://doi.org/10.1590/S0034-71672003000200015

MOURA, E. R. F.; BEZERRA, C. G.; OLIVEIRA, M. S.; DAMASCENO, M. M. C. Validação de jogo educativo destinado à orientação dietética de portadores de diabetes mellitus. Rev APS., v. 11, n. 4, p. 435-43, out-dez. 2008.

OLIVEIRA, M. C.; LUCENA, A. F.; ECHER, I. C. Neurological sequelae: preparation of a guidance manual for health care. J Nurs UFPE on line, v. 8, n. 6, p. 1597-603, jun. 2014.

OLIVEIRA, M. S. Autocuidado da mulher na reabilitação da mastectomia: estudo de validação de aparência e conteúdo de uma tecnologia educativa. 2006. 114 f. Dissertação (Mestrado em Enfermagem) Curso de Pós-Graduação em Enfermagem, Universidade Federal do Ceará, Fortaleza, 2006.

OLIVEIRA, M. S.; FERNANDES, A. F. C.; SAWADA, N. O. Manual educativo para o autocuidado da mulher mastectomizada: um estudo de validação. Texto \& Contexto Enferm., v. 17, n. 1, p. 115-23, 2008. https://doi.org/10.1590/S0104-07072008000100013

OLIVEIRA, S. C.; LOPES, M. V. O.; FERNANDES, A. F. C. Development and validation of an educational booklet for healthy eating during pregnancy. Rev. Latino-Am. Enfermagem, v. 22, n. 4, p. 611-20, jul-aug. 2014. https://doi.org/10.1590/0104-1169.3313.2459

PASQUALI, L. Psicometria: teoria e aplicações. Brasília: Editora Universidade de Brasília, 1997. 289 p.

PAULA, J. M.; SONOBE, H. M.; NICOLUSSI, A. C.; ZAGO, M. M. F.; SAWADA, N. O. Symptoms of depression in patients with cancer of the head and neck undergoing radiotherapy treatment: a prospective study. Rev Latino-Am Enferm., v. 20, n. 2, p. 362-8, mar-apr. 2012. https://doi.org/10.1590/S010411692012000200020

POLIT, D. F.; BECK, C. T. Fundamentos de pesquisa em enfermagem: avaliação de evidências para a prática da enfermagem. 7. ed. Porto Alegre: Artmed, 2011. 669 p.

SALLES, P. S.; CASTRO, R. C. B. R. Validação de material informativo a pacientes em tratamento quimioterápico e aos seus familiares. Rev Esc Enferm USP, v. 44, n. 1, p. 182-9, 2010. https://doi.org/10.1590/S0080-62342010000100026

SOUSA, C. S.; TURRINI, R. N. T. Creating and validating educational material for patients undergoing orthognathic surgery. Asian Nursing Research, v. 6, n. 4, p. 166-72, dec. 2012. https://doi.org/10.1016/j.anr.2012.10.006 